\title{
Upaya Meningkatkan Keterampilan Teknik Menumpu Lompat Jauh Gaya Menggantung Dengan Menggunakan Metode Bermain Pada Siswa Kelas VIII A MTs Unggulan Nuris Jember
}

\author{
Ahmad Bahriyanto \\ Prodi Pendidikan Olahraga, Universitas Muhammadiyah Jember \\ Email: bahriyantoahmad@gmail.com
}

\begin{abstract}
ABSTRAK
Penelitian ini bertujuan untuk meningkatkan keterampilan siswa pada lompat jauh gaya menggantung khususnya pada teknik menumpu dengan menggunakan metode bermain pada siswa kelas VIII A MTs Unggulan Nuris Jember. Penelitian ini merupakan jenis penelitian tindakan kelas. Pelaksanaan tindakan kelas ini dilakukan melalui dua siklus dimana tiap siklus terdiri dari 4 tahap yaitu: (1) perencanaan, (2) pelaksanaan, (3) observasi, (4) refleksi. Subjek dalam penelitian ini adalah siswa kelas VIII A MTs Unggulan Nuris Jember. Hasil penelitian ini menunjukkan bahwa terjadi peningkatan pada keterampilan menumpu siswa selama mengikuti pembelajaran lompat jauh gaya menggantung dari siklus ke siklus. Pada siklus 1 dari aspek ketepatan kaki pada papan tumpu yang melakukan dengan benar sebesar $52,51 \%$, aspek posisi badan yang melakukan dengan benar sebesar $67,77 \%$, aspek gerakan tumpuan kaki tumpu pada papan tumpu yang melakukan dengan benar sebesar $90,90 \%$, dan pada aspek ayunan kaki dan lengan yang melakukan dengan benar sebesar $57,57 \%$. Dari hasil tersebut menunjukkan peningkatan terhadap penguasaan keterampilan lompat jauh gaya menggantung khususnya pada teknik menumpu yang terlihat dari perbandingan hasil pre-test yang dilaksanakan pada saat sebelum tindakan dengan hasil post-test yang diberikan pada akhir tindakan. Untuk hasil dari siklus 2 juga menunjukkan peningkatan penguasaan keterampilan lompat jauh gaya menggantung khususnya pada teknik menumpu dengan masing masing taraf keberhasilan dari aspek menumpu diantaranya, dari aspek ketepatan kaki pada papan tumpu yang melakukan dengan benar sebesar $93,94 \%$, aspek posisi badan yang melakukan dengan benar sebesar $100 \%$, aspek gerakan tumpuan kaki tumpu pada papan tumpu yang melakukan dengan benar sebesar 100\%, dan pada aspek ayunan kaki dan lengan yang melakukan dengan benar sebesar $96,97 \%$. Selain hasil persentasi mengenai teknik menumpu pada lompat jauh gaya menggantung diperoleh pula hasil pengamatan sikap siswa pada saat proses pembelajaran, pada siklus 1 siswa melakukan pemanasan sendiri tanpa didampingi oleh guru, siswa yang terlambat tidak ditegur oleh guru, dan siswa tidak memperhatikan penjelasan guru saat guru menjelaskan. Namun pada siklus 2 sudah terlihat peningkatan yang cukup baik dibandingkan dengan siklus 1 , pada siklus 2 ini sudah tidak ada siswa yang terlambat, siswa melakukan proses belajar dengan baik, dan siswa sudah menguasai keterampilan menumpu dengan baik dan benar.
\end{abstract}

Kata kunci: Peningkatan, Keterampilan, Lompat Jauh Gaya Menggantung, Metode Bermain.

\section{PENDAHULUAN}

Aktifitas permainan dan olahraga merupakan salah satu ruang lingkup dari mata pelajaran Pendidikan Jasmani Olahraga dan Kesehatan yang terdapat dalam standart kompetensi Sekolah Menengah Pertama Kelas VIII. Salah satu kompetensi dasarnya yaitu mempraktikkan teknik dasar salah satu permainan olahraga atletik lanjutan dengan koordinasi yang baik serta nilai kerjasama, toleransi, percaya diri, keberanian, menghargai lawan, bersedia berbagi tempat dan peralatan.

Atletik merupakan salah satu cabang olahraga yang tertua yang dilakukan oleh manusia sejak jaman Yunani Kuno sampai saat ini, yang dipelajari dalam cabang olahraga atletik ini yaitu berjalan, berlari, melompat dan melempar. Dalam kejuaraan altetik ada beberapa nomor yang 
diperlombakan yang terdiri atas nomor-nomor jalan, lari, lompat, dan lempar. Dari keempat nomor yang diperlombakan tersebut yang akan dibahas lebih lanjut adalah pada nomor lompat jauh.

Untuk memperoleh data awal, peneliti menggunakan empat teknik dasar dalam lompat jauh yaitu awalan, tumpuan, melayang dan cara melakukan pendaratan yang digunakan sebagai tolak ukur penelitian. Salah satu contoh berdasarkan observasi yang dilakukan terhadap kelas VIII A MTs Unggulan Nuris diperoleh persentase seperti pada tabel sebagai berikut:

Tabel 1. Data Hasil Observasi Lompat Jauh Gaya Menggantung

\begin{tabular}{lllllllll}
\hline \multirow{2}{*}{ Teknik } & \multicolumn{3}{c}{ Awalan } & \multicolumn{3}{c}{ Menumpu } & Melayang & \multicolumn{2}{c}{ Mendarat } \\
\cline { 2 - 9 } & Salah & Benar & Salah & Benar & Salah & Benar & Salah & Benar \\
\hline Jumlah & 6 & 27 & 20 & 13 & 12 & 21 & 9 & 24 \\
\hline Rata-rata kegagalan & $18,19 \%$ & $81,81 \%$ & $60,60 \%$ & $39,39 \%$ & $36,36 \%$ & $63,63 \%$ & $27,27 \%$ & $72,72 \%$
\end{tabular}

Dari hasil pengamatan melalui tabel di atas dapat dinyatakan bahwa yang banyak muncul adalah pada teknik menumpu. Jumlah siswa kelas VIII A adalah 33 siswa, 15 diantaranya laki-laki dan 18 siswa perempuan. Dari hasil observasi diatas diperoleh $60,60 \%$ siswa yang mengalami kesulitan pada saat melakukan tumpuan yang diantaranya 20 siswa melakukan gerakan yang salah dan 13 siswa yang melakukan gerakan dengan benar. Kemudian dari hasil observasi tersebut peneliti mencari kembali faktor yang menyebabkan siswa mengalami kesulitan melakukan teknik menumpu, karena hal tersebut peneliti menggunakan empat teknik dasar melakukan gerakan teknk menumpu yaitu ketepatan kaki pada papan tumpu, posisi badan, gerakan tumpuan kaki , ayunan kaki dan lengan. Salah satu contoh berdasarkan observasi yang dilakukan terhadap kelas VIII A diperoeh data pada tabel sebagai berikut:

Tabel 2. Analisis Teknik Menumpu Lompat Jauh Gaya Menggantung

\begin{tabular}{|c|c|c|c|c|c|c|c|c|}
\hline \multirow[t]{2}{*}{$\begin{array}{l}\text { Teknik } \\
\text { Menumpu }\end{array}$} & \multicolumn{2}{|c|}{$\begin{array}{l}\text { Ketepatan kaki pada } \\
\text { papan tumpu }\end{array}$} & \multicolumn{2}{|c|}{ Posisi badan } & \multirow{2}{*}{$\begin{array}{l}\begin{array}{l}\text { Gerakan } \\
\text { kaki }\end{array} \\
\text { Salah }\end{array}$} & tumpuan & \multirow{2}{*}{$\begin{array}{l}\begin{array}{l}\text { Ayunan } \\
\text { lengan }\end{array} \\
\text { Salah }\end{array}$} & \multirow{2}{*}{$\begin{array}{c}\text { kaki dan } \\
\text { Benar }\end{array}$} \\
\hline & Salah & Benar & Salah & Benar & & Benar & & \\
\hline Jumlah & 22 & 11 & 19 & 14 & 8 & 25 & 18 & 15 \\
\hline $\begin{array}{l}\text { Rata-rata } \\
\text { kegagalan }\end{array}$ & $66,66 \%$ & $33,33 \%$ & $57,57 \%$ & $42,42 \%$ & $24,24 \%$ & $75,75 \%$ & $54,54 \%$ & $45,45 \%$ \\
\hline
\end{tabular}

Dari hasil analisis di atas, peneliti telah menemukan beberapa tingkat kesalahan yang dilakukan oleh siswa yaitu: 22 siswa melakukan kesalahan pada saat menempatkan kaki pada papan tumpu, 19 siswa pada saat posisi badan, 8 siswa pada saat gerakan tumpuan kaki, 18 siswa melakukan kesalahan ayunan lengan dan tangan. Dari hasil pengamatan tersebut peneliti menarik kesimpulan bahwa siswa mengalami kesulitan pada saat melakukan tumpuan. Kesalahan yang sering terjadi yaitu ketidaktepatan kaki pada saat menumpu pada papan tumpu.

\section{METODE}

Bermain merupakan suatu kegiatan yang menyenangkan. Kegiatan bermain sangat disukai oleh para siswa. Bermain yang dilakukan secara tertata, mempunyai manfaat yang besar bagi perkembangan siswa. Bermain dapat memberikan pengalaman belajar yang sangat berharga bagi siswa. Pengalaman itu bisa berupa membina hubungan dengan sesama teman dan menyalurkan perasaan tertekan (Saputra.YM, 2001:6).

$$
\text { Manfaat bermain untuk }
$$
pengembangan keterampilan Olahraga. 
Apabila siswa terampil berlari, melempar, dan melompat, maka dia akan lebih siap untuk menekuni bidang olahraga tertentu pada saatnya nanti. Jadi, kalau siswa terampil pada kegiatan tersebut, ia lebih percaya diri dan merasa mampu melakukan gerakan yang lebih sulit. Kegiatan-kegiatan yang lebih relevan, dengan perkembangan siswa adalah atletik.

Pembelajaran dengan menggunakan metode bermain pada materi lompat jauh hal ini akan dapat meningkatkan keterampilan siswa, karena dengan bermain siswa akan merasa senang dan bersemangat untuk melakukan kegiatan pembelajaran yang diberikan oleh guru dan secara tidak langsung siswa tersebut melakukan gerakan secara terus-menerus yang bertujuan untuk meningkatkan pembelajaran tersebut.

Dalam pembelajaran teknik menumpu, metode bermain yang akan digunakan pada penelitian ini untuk meningkatkan keterampilan menumpu pada lompat jauh gaya menggantung adalah sebagai berikut: (1) Bermain lompat teman, (2) Bermain lompat gelang, (3) Bermain lompat mistar, (4) Bermain menyundul bola. Dari uraian di atas dapat disimpulkan bahwa metode bermain adalah cara yang digunakan untuk mencapai tujuan dan bermain adalah alat untuk mencapai tujuan tersebut, yang bersifat menyenangkan, serius, dan sukarela.

\section{HASIL}

Berdasarkan hasil penelitian yang sudah dilaksanakan tentang peningkatan keterampilan teknik menumpu pada lompat jauh gaya menggantung siswa kelas VIII A MTs Unggulan Nuris Jember dengan menggunakan metode bermain. Variasivariasi permainan yang dikembangkan oleh peneliti dan telah dimodifikasi khususnya pada latihan teknik menumpu yang pada observasi awal tingkat kesalahan yang terjadi paling tinggi.

Jenis permainan yang digunakan oleh peneliti sudah dimodifikasi dan disesuaikan dengan tujuan pada penelitian yaitu untuk meningkatkan keterampilan teknik menumpu pada lompat jauh gaya menggantung. Permainan-permainan tersebut diantaranya lompat teman, lompat gelang, lompat mistar dan menyundul bola. Selain permainan tersebut peneliti juga memberikan bentuk variasi latihan dalam pembelajaran teknik menumpu, diantaranya: lompat kijang, lompat zig-zag dan lompat lay-up.

Pada siklus 1 pembelajaran yang berlangsung terdiri dari 4 tahap yaitu, perencanaan, pelaksanaan, pengamatan dan refleksi. Dalam tahap perencanaan peneliti merancang Rencana Pelaksanaan Pembelajaran dan model-model permainan yang akan digunakan dalam pembelajaran yang kemudian akan didiskusikan dengan guru Pendidikan Jasmani. Pada tahap pelaksanaaan, pembelajaran dilakukan dalam 3 kali pertemuan dimana setiap pertemuan diberikan metode-metode permainan yang berbeda, hal itu dilakukan agar siswa merasa tertarik untuk melakukan kegiatan pembelajaran, dengan rasa ketertarikan tersebut maka siswa akan lebih giat dan akan melakukan berulang-ulang dan secara otomatis akan membuat siswa menguasai materi dengan cepat. Pada tahap pengamatan kegiatan yang dilakuakan yaitu mengumpulkan data hasil dari pengamatan dari setiap pertemuan yang dicatat pada lembar observasi di setiap pertemuan. Dan untuk tahap terakhir yaitu tahap refleksi dalam tahap ini peneliti dan guru Pendidikan Jasmani mendiskusikan mengenai hasil dari pembelajaran pada siklus 1 dan menentukan apakah sudah memenuhi target yang diinginkan atau masih perlu dilanjutkan pada siklus 2. Jenis-jenis permainan yang diberikan pada pembelajaran yaitu permainan lompat teman, lompat gelang, lompat mistar dan meyundul bola yang masing-masing permainan tersebut berguna untuk melatih ketepatan kaki pada papan tumpu, posisi badan, gerakan kaki tumpu pada balok tumpu serta melatih ayunan kaki dan lengan. Pada siklus pertama siswa melakukan keterampilan menumpu sudah menagalami peningkatan dari sebelum diberikan tindakan, persentase peningkatan teknik menumpu diantaranya pada aspek ketepatan kaki pada papan tumpu yang dilakukan dengan benar oleh siswa adalah $52,51 \%$ dikategorikan cukup baik, aspek posisi badan yang dilakukan oleh siswa dengan gerakan yang benar adalah $67,66 \%$ dikategorikan cukup baik, aspek gerakan kaki pada saat berada pada papn 
tumpu yang dilakukan oleh siswa dengan gerakan yang benar adalah 90,90\% dikategorikan baik, dan aspek ayunan kaki dan lengan yag dilakukan oleh siswa dengan gerakan yang benar adalah $57,57 \%$ dikategorikan cukup baik. Dilihat dari jumlah persentase, tingkat kesalahan paling banyak terjadi yaitu pada teknik ketepatan posisi kaki pada papan tumpu yaitu dengan persentase $52,51 \%$ dikategorikan cukup baik, akan tetapi kesalahan yang dialami oleh siswa sudah ada peningkatan. Kesalahan yang terjadi yaitu tetap pada kaki tumpu siswa tidak tepat pada papan tumpu, ketidak ketepatan pada papan tumpu ini posisi kaki siswa yang belum menginjak papan tumpu atau melebihi papan tumpu serta keragu-raguan siswa saat akan mendekati papan tumpu. Karena pada siklus 1 masih kurang adanya peningkatan yang sesuai dengan harapan peneliti, maka penelitian dilanjutkan pada siklus 2 untuk memperoleh peningkatan yang lebih baik.

\section{Siklus 2}

Pada siklus 2 pembelajaran yang berlangsung sama dengan siklus 1 yaitu terdiri dari 4 tahap yaitu, perencanaan, pelaksanaan, pengamatan dan refleksi. Dalam tahap perencanaan peneliti merancang Rencana Pelaksanaan Pembelajaran dan model-model permainan yang akan digunakan dalam pembelajaran yang kemudian akan didiskusikan dengan guru Pendidikan Jasmani. Pada tahap pelaksanaaan, pembelajaran dilakukan dalam 3 kali pertemuan dimana setiap pertemuan diberikan metode-metode permainan yang berbeda, hal itu dilakukan agar siswa merasa tertarik untuk melakukan kegiatan pembelajaran, dengan rasa ketertarikan tersebut maka siswa akan lebih giat dan akan melakukan berulang-ulang dan secara otomatis akan membuat siswa menguasai materi dengan cepat. Pada tahap pengamatan kegiatan yang dilakuakan yaitu mengumpulkan data hasil dari pengamatan dari setiap pertemuan yang dicatat pada lembar observasi di setiap pertemuan. Dan untuk tahap terakhir yaitu tahap refleksi peneliti dan guru Pendidikan Jasmani mendiskusikan mengenai hasil dari pembelajaran pada siklus 2 dan menentukan apakah sudah memenuhi target yang diinginkan. Jenis-jenis permainan yaitu permainan lompat teman, lompat gelang, lompat mistar, menyundul bola dan meyentuh bola yang masing-masing permainan tersebut berguna untuk melatih ketepatan kaki pada papan tumpu, posisi badan, gerakan kaki tumpu pada balok tumpu serta melatih ayunan kaki dan lengan. Serta pada siklus kedua ini sedikit diberikan variasi pada pembelajaran, pada siklus 2 siswa sudah lebih menguasai pembelajaran yang diberikan oleh guru daripada siklus 1 .

Pada siklus kedua siswa melakukan keterampilan menumpu sudah mengalami peningkatan dari siklus petama, persentase peningkatan teknik menumpu diantaranya pada aspek ketepatan kaki pada papan tumpu yang dilakukan dengan benar oleh siswa yang sebelumnya $52,51 \%$ menjadi 93,94\% dikategorikan baik, aspek posisi badan yang dilakukan oleh siswa dengan gerakan yang benar yang sebelumnya $67,66 \%$ menjadi $100 \%$ dikategorikan baik, aspek gerakan kaki pada saat berada pada papn tumpu yang dilakukan oleh siswa dengan gerakan yang benar yang sebelumnya $\quad 90,90 \%$ menjadi $\quad 100 \%$ dikategorikan baik, dan aspek ayunan kaki dan lengan yag dilakukan oleh siswa dengan gerakan yang benar yang sebelumnya $57,57 \%$ menjadi $96,97 \%$ dikategorikan baik. Meskipun hasil yang diperoleh belum maksimal, akan tetapi hasil keterampilan yang diperoleh pada siklus 2 sudah meningkat lebih baik dari siklus 1 , kesalahan yang terjadi yaitu tetap pada kaki tumpu siswa yang tidak tepat pada papan tumpu.

\section{Perbandingan Keaktifan Siswa Pada Siklus 1 dan Siklus 2}

Pada siklus 1 Selain hasil persentasi mengenai teknik menumpu pada lompat jauh gaya menggantung, diperoleh pula hasil dari pengamatan sikap siswa pada saat proses pembelajaran, yaitu pada siklus 1 khususnya pada pertemuan pertama siswa masih melakukan pemanasan sendiri tanpa didampingi oleh guru, siswa yang terlambat tidak ditegur oleh guru, siswa yang menyimpang tidak segera ditegur oleh guru, dan siswa tidak memperhatikan penjelasan guru saat guru menjelaskan materi, namun setelah pertemuan ke dua dan ketiga mulai 
ada kemajuan sikap siswa seperti, siswa yang datang terlambat dan sudah ditegur oleh guru, siswa memperhatikan penjelasan guru saat guru menjelaskan materi, pengaturan waktu tiap-tiap latihan atau permainan sudah terinci dengan baik.

Pada siklus 2 selain hasil persentasi mengenai teknik menumpu pada lompat jauh gaya menggantung, diperoleh pula hasil dari pengamatan sikap siswa pada saat proses pembelajaran, dibandingkan dengan hasil pengamatan pada siklus 1 maka pada siklus kedua ini sudah terlihat peningkatan yang cukup baik, sudah tidak ada siswa yang terlambat, siswa yang menyimpang menjadi lebih disiplin, siswa melakukan proses belajar dengan baik, dan siswa sudah menguasai keterampilan menumpu dengan baik dan benar.

\section{Perbandingan Keterampilan Siswa Pada Siklus 1 dan Siklus 2}

Pada siklus 1 keterampilan siswa mengalami sedikit peningkatan dari yang sebelum diberikan tindakan, akan tetapi pada siklus 2 keterampilan siswa pada teknik menumpu sudah meningkat dengan baik. Peningkatan tersebut dapat dilihat dari table 5.1 yaitu:

Table 3. Perbandingan Keterampilan Siswa Pada Siklus 1 dan Siklus 2

\begin{tabular}{clccc}
\hline & Indikator Keterampilan & $\begin{array}{c}\text { Siklus 1 } \\
(\%)\end{array}$ & $\begin{array}{c}\text { Siklus 2 } \\
(\%)\end{array}$ & $\begin{array}{c}\text { Peningkatan } \\
(\%)\end{array}$ \\
\hline 1. & Ketepatan kaki pada papan tumpu & 52,51 & 93,94 & 78,89 \\
\hline 2. & Posisi badan & 67,66 & 100 & 47,79 \\
\hline 3. & Gerakan tumpuan kaki & 90,90 & 100 & 10,01 \\
\hline 4. & Ayunan kaki dan lengan & 57,57 & 96,97 & 68,43 \\
\hline & Jumlah & $\mathbf{2 6 8 , 6 4}$ & $\mathbf{3 9 0 , 9 1}$ & \\
\hline & Rata-rata & $\mathbf{6 7 , 1 6}$ & $\mathbf{9 7 , 7 2}$ & $\mathbf{5 1 , 2 8}$ \\
\hline
\end{tabular}

Berdasarkan pada table diatas diketahui bahwa indikator ketepatan kaki pada papan tumpu mengalami peningkatan sebesar $78,89 \%$, indikator pada posisi badan mengalami peningkatan sebesar $47,79 \%$, indikator gerakan tumpuan kaki pada saat berada pada papan tumpu mengalami peningkatan sebesar $10,01 \%$ dan indikato pada ayunan kaki dan lengan mengalami peningkatan sebesar $68,43 \%$.

Dari uraian diatas maka model pembelajaran yang digunakan dapat meningkatkan keterampilan menumpu siswa pada lompat jauh gaya menggantung, keterampilan menumpu siswa dapat diukur dengan indikator ketepatan kaki pada papan tumpu, posisi badan, gerakan tumpuan kaki, dan ayunan kaki dan lengan. Hal ini sejalan dengan instrument penilaian keterampilan menumpu yang dikembangkan oleh Roji (2006:83) yang menjabarkan keterampilan teknik menumpu menjadi 4 indikator yaitu ketepatan kaki pada papan tumpu, posisi badan, gerakan tumpuan kaki, dan ayunan kaki dan lengan.

\section{PENUTUP}

Penggunaan model pembelajaran dengan metode bermain dapat meningkatkan keterampilan teknik menumpu pada pembelajaran lompat jauh gaya menggantung siswa kelas VIII A MTs Unggulan Nuris Jember. Peningkatan hasil keterampilan teknik menumpu siswa dapat dilihat pada silklus 1 diantaranya pada aspek ketepatan kaki pada papan tumpu yang dilakukan dengan benar oleh siswa adalah $52,51 \%$ dikategorikan cukup baik, aspek posisi badan yang dilakukan oleh siswa dengan gerakan yang benar adalah $67,66 \%$ dikategorikan cukup baik, aspek gerakan kaki pada saat berada pada papn tumpu yang dilakukan oleh siswa dengan gerakan yang benar adalah 90,90\% dikategorikan baik, dan aspek ayunan kaki dan lengan yag dilakukan oleh siswa dengan gerakan yang benar adalah $57,57 \%$ dikategorikan cukup baik. Sedangkan pada siklus 2 keterampilan siswa meningkat lebih baik dari siklus yang pertama diantarnya pada aspek ketepatan kaki pada papan tumpu yang dilakukan dengan benar oleh siswa adalah 93,94\% dikategorikan baik, aspek posisi badan yang dilakukan oleh siswa dengan gerakan yang benar adalah 
$100 \%$ dikategorikan baik, aspek gerakan kaki pada saat berada pada papan tumpu yang dilakukan oleh siswa dengan gerakan yang benar adalah 90,90\% menjadi 100\% dikategorikan baik, dan aspek ayunan kaki dan lengan yang dilakukan oleh siswa dengan gerakan yang benar adalah $96,97 \%$ dikategorikan baik.

\section{DAFTAR PUSTAKA}

Arikunto, Suharsimi. 2008. Penelitian Tindakan Kelas. Jakarta: Bumi Aksara.

Dimyati \& Mudjiono. 1994. Belajar dan Pembelajaran. Jakarta

Ekawarna, 2009. Penelitian Tindakan Kelas. Jakarta: Gaung Persada.

Evaluasi Belajar Mandiri. Solo: PT. Media Karma. (Lembar Kerja Siswa).

Furqon H, M. 2006. Mendidik Anak dengan Bermain. Surakarta : Universitas Sebelas Maret.

Gerry A. Carr. 2000. Atletik Untuk Sekolah. PT RajaGrafindo. Jakarta.

SaputraY,P. 2001. Dasar- Dasar Keterampilan Atletik. Jakarta: Direktorat Jenderal Pendidikan Dasar \& Menengah.

Suherman, Adang. 2001. Pembelajaran Atletik. Depdiknas. Jakarta.

Universitas Negeri Malang. 2011. Pedoman Penulisan Karya Ilmiah. Malang: Universitas Negeri Malang.

Winarno, M.E. 2007. Metodologi Penelitian Dalam Pendidikan Jasmani. Malang: Universitas Negeri Malang.

Wiriaatmaja, Rochiati. 2006. Metode Penelitian Tindakan Kelas. Bandung: Remaja Rosdakarya. 